\title{
Applied Anatomy of the Femoral Veins in Macaca fascicularis
}

\author{
Anatomía Aplicada de las Venas Femorales en Macaca fascicularis
}

Yong-Zhen Zhang; Xi Zhang; Shao-Hu Xiong; Bing Nie; Man-Ru Shen;

Zhen Liu; Jian-Ming Yuan; Rui-Shan Dang \& Chuan-Sen Zhang

ZHANG, Y.; ZHANG, X.; XIONG, S.; NIE, B.; SHEN, M.; LIU, Z.; YUAN, J.; DANG, R. \& ZHANG, C. Applied anatomy of the femoral veins in Macaca fascicularis. Int. J. Morphol., 30(4):1327-1331, 2012.

SUMMARY: The aim was to understand the anatomical features of the venous valve in Macaca fascicularis and to compare it with that of humans. The bilateral lower limbs (24 limbs from 12 animals) of Macaca fascicularis cadavers were dissected, and the femoral veins (FVs) were equally divided into distal, intermediate, and proximal sections. The external diameter of the FV in each section was measured. The venous valves were observed microscopically and stained with hematoxylin and eosin as well as trichrome. Data describing the human venous valve were collected from the current literature. No great saphenous veins were found among the 24 lower limbs from the Macaca fascicularis cadavers. The external diameters of the FVs in the distal, intermediate, and proximal sections were $3.53 \pm 0.37 \mathrm{~mm}, 3.42 \pm 0.55 \mathrm{~mm}$, and 3.37 $\pm 0.54 \mathrm{~mm}$, respectively. In most cases, there was one venous bivalve located in the FV approximately $0-2.71 \mathrm{~mm}$ below the junction of the FV and the deep femoral vein. Endothelium covered the luminal and sinusal surfaces of the leaflets. Abundant collagen fibers were found under the endothelial cells beneath the luminal surface of the leaflets. An elastin fiber network was located under the sinus endothelial surface. Smooth muscle cells in the FV extend to the edge of the valve. The venous valve of Macaca fascicularis is similar to that of humans, both morphologically and histologically. However, there is only one venous bivalve and no great saphenous vein in Macaca fascicularis.

KEY WORDS: Femoral vein; Venous valve; Primate; Applied anatomy; Macaca fascicularis.

\section{INTRODUCTION}

Chronic venous insufficiency (CVI) in lower limbs is a severe disease (Traber et al., 2009) that accounts for approximately $\$ 1$ billion in health care costs in the United States per year. Animal models of CVI have been established in rats, sheep, and pigs (Gillet et al., 2006). However, the locomotor repertoires of those animals are quite different from that of humans, resulting in questionable results. Nonhuman primates are closely related to humans (Bontrop, 2001), with 95\% genetic similarity (Boffelli et al., 2003). The locomotor repertoire of nonhuman primates is also similar to that of humans (Inaba et al., 2007). However, the extent of the similarities of the femoral vein (FV) and venous valve in primates and humans in unknown. An understanding of the number and location of the venous valves in nonhuman primates is important for the study of CVI, which is poorly understood. In the present study, the FVs and venous valves in Macaca fascicularis, a commonly used laboratory primate, were anatomically and histopathologically described. The location and number of the venous valves were recorded, and a comparison was made between the FVs of Macaca fascicularis and humans.

\section{MATERIAL AND METHOD}

The FVs of the bilateral lower limbs, derived from 12 Macaca fascicularis that were sacrificed in another experiment, were studied. The FVs and their tributaries were dissected, and the general morphological characteristics were recorded. The length of the FVs from the midpoint of the inguinal ligament to the popliteal vein were measured in situ with a sliding caliper $(0.01 \mathrm{~mm})$. The FVs were then harvested arranged in the anatomical position. The blood clots in the FVs were then removed. Each vessel was flattened and equally divided into three sections. The external diameter of each section was measured.

Then, the veins were cut open and examined under a dissecting microscope to study the number and shape of the valves. The junction between the FV and the deep femoral vein (DFV) was chosen as the reference point for describing the valve positions. The exact position and distance of each valve relative to the junction was measured. Then, the selected specimens with their associated venous valves were fixed in $10 \%$ formaldehyde for 1 day, dehydrated in a graded ethanol series, embedded in paraffin, and cut into $10-\mu \mathrm{m}$

Institute of Biomedical Engineering, Second Military Medical University, Shanghai, China.

This work was supported by the National Natural Science Foundation of China (No. 30672045), the Shanghai Natural Science Foundation (No. 08441900600) and the Military Project (No. CWS12J087). 
sections. The sections were stained with hematoxylin/eosin (HE) and Masson trichrome and observed with an optical microscope. The venous structure and the organization of the collagen fibers, elastic fibers, and the smooth muscles were studied. Data are expressed as mean \pm SD.

\section{RESULTS}

Macroscopic Anatomy. The FV consists of the superficial $\mathrm{FV}$ and the common vein from the adductor hiatus to the intersection of the inguinal ligament. The mean length of the $24 \mathrm{FVs}$ was $37.28 \pm 2.32 \mathrm{~mm}$, ranging from 42.18 to $34.70 \mathrm{~mm}$. The outer diameters of the distal, middle, and proximal sections of the FVs were $3.53 \pm 0.37 \mathrm{~mm}, 3.41 \pm$ $0.55 \mathrm{~mm}$, and $3.37 \pm 0.54 \mathrm{~mm}$, respectively. There were few venous branches and no great saphenous vein branches among the 24 specimens (Fig.1 and Table.I). Among the 24 FVs, 23 contained one valve. The valve was consistently presented immediately distal to the junction between the FV and the DFV. The junction was used as the reference point for the valve position. The valves were present in $95.8 \%$ of all specimens at a distance of $0-2.71 \mathrm{~mm}$ from the junction. The forms of the venous valve included bivalve $(83.3 \%, 20$ specimens, Fig. 2A), trivalve ( $8.3 \%$, 2 specimens, Fig. 2B), and univalve (4.1\%, 1 specimen, Fig. 2C). One limb FV had no valves throughout the FV.

Histopathological features. The endothelium covers the luminal and sinusal surfaces of the leaflets, and the main component of the leaflets are collagen fibers between the two layers of endothelium. Elastic fibers exist beneath the luminal surface (Fig. 4). Smooth cells extend from the wall of the vein to the base of venous valve (Figs. 3 and 4).

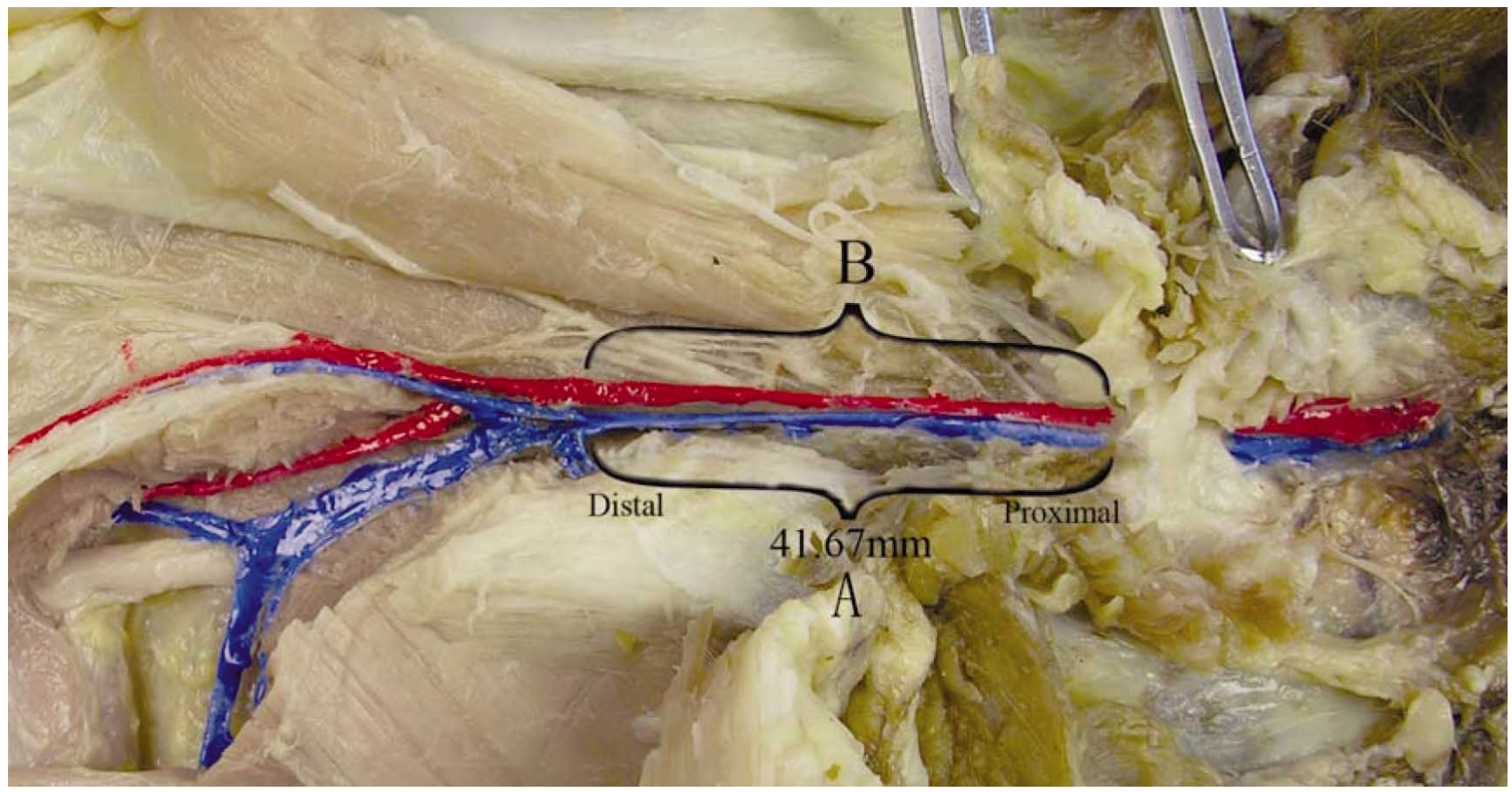

Fig. 1 Macroscopic evaluation of the femoral veins. (A) the femoral vein (blue); (B) the femoral artery (red); there were no great saphenous vein branches in the FV.

External diameters and lengths of the femoral veins (mm).

\begin{tabular}{lccr}
\hline & Max & Min & Mean \pm SD \\
\hline Proximal 1/3 & 4.17 & 2.98 & $3.53 \pm 0.37$ \\
Intermediate 1/3 & 4.16 & 2.45 & $3.42 \pm 0.55$ \\
Distal 1/3 & 4.12 & 2.48 & $3.37 \pm 0.54$ \\
length & 42.18 & 34.70 & $37.28 \pm 2.32$ \\
\hline \multicolumn{4}{l}{ Values are mean \pm SE from 24 FVs in 12 Macaca fascicularis. }
\end{tabular}



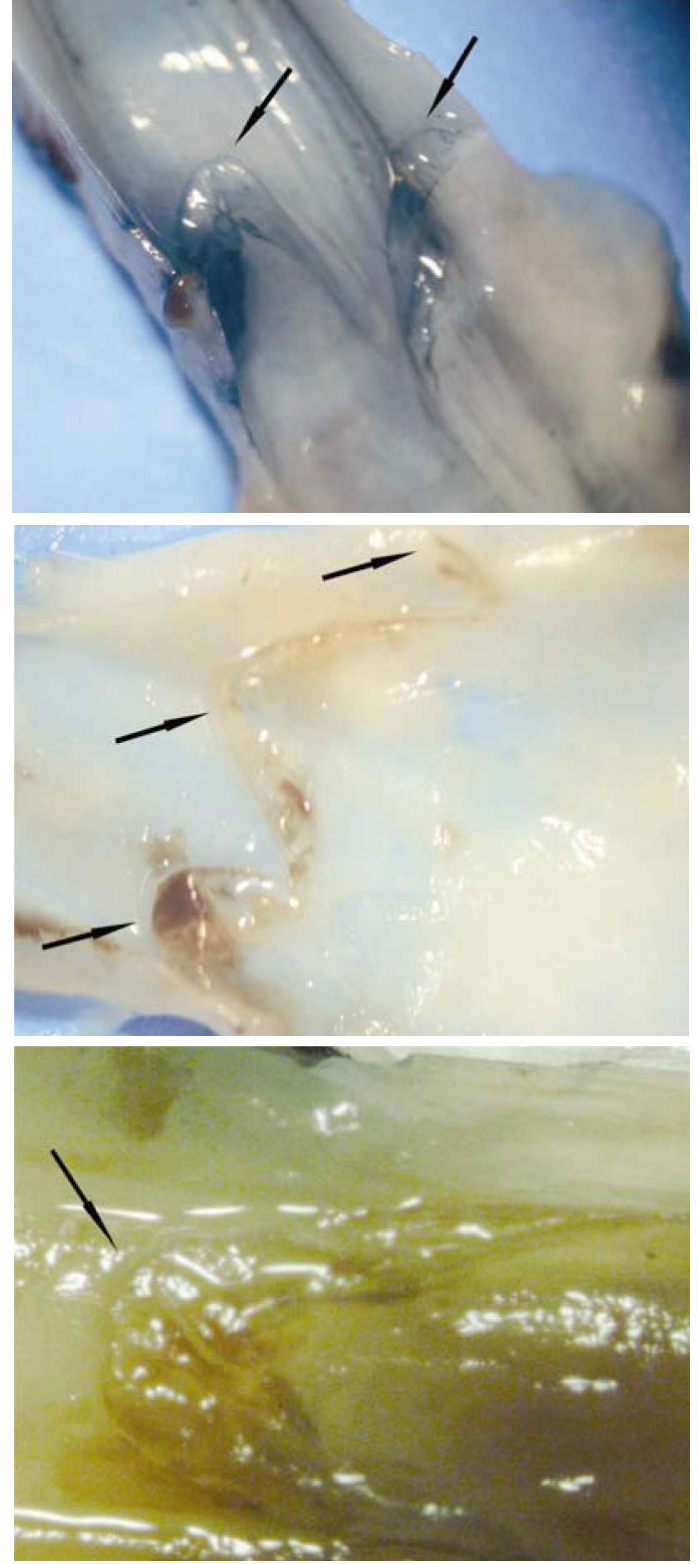

Fig. 2 Forms of femoral venous valves. (A) bivalve; (B) trivalve; (C) univalve. Blank arrows mark the presence of femoral venous valves.

\section{DISCUSSION}

Nonhuman primates are good animal models for CVI because they are highly similar to humans in a variety of ways. First, primates have a locomotor repertoire that is similar to that of humans, including movements such as jumping, crawling, bipedal movement, and suspension movement. Second, the immunological

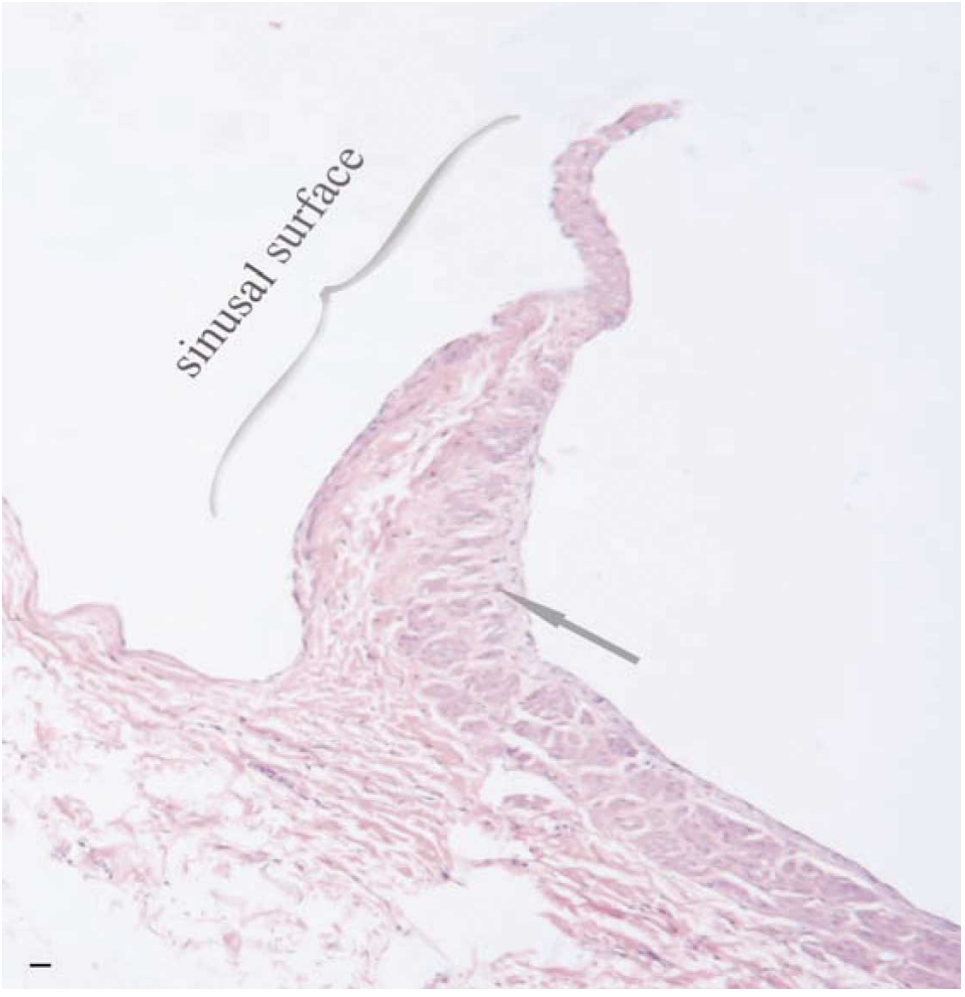

Fig. $3 \mathrm{HE}$ staining of the venous valve in a longitudinal section. Gray arrows mark the presence of smooth muscle. Scale bar $=30 \mu \mathrm{m}$

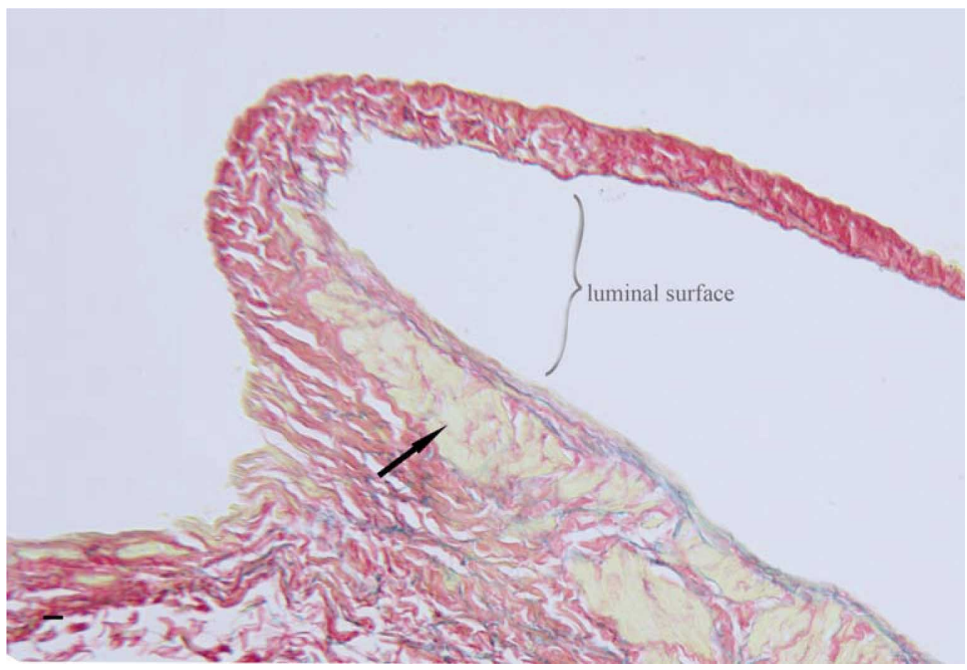

Fig. 4 Masson staining of the venous valve in a longitudinal section. Blank arrows mark the presence of smooth muscle; elastin fiber (blue); collagen fibers (red). Scale bar $=30 \mu \mathrm{m}$.

characteristics of primates are similar to those of humans. For example, the human leukocyte antigen antibodies and primate major histocompatibility complex are cross-reactive (Qi et al., 2000). Finally, it has been shown that the hemostatic system of primates is very similar to that of humans (Harker et al., 1991). 
Lower limb CVI is usually caused by failure of the valves in the superficial or deep veins of the lower limbs. It is important to understand the anatomical structure of superficial veins, deep veins and their valves in lower limbs for the pathogenicity and animal models of CVI. There are data abundant in human anatomical structure of lower limb veins and valves. The anatomical structures of superficial veins and their valves in nonhuman primates lower limbs have been detailedly described (Thiranagama et al., 1989). However, there is very little published information regarding FV stems and their valves in nonhuman primates.

The results of this study show that there are similarities between Macaca fascicularis and humans with respect to the location of constant valve and common form of the venous valves. Human FVs have one to six valves, some of which are consistently located at specific locations. The most common site for a valve is just distal to the junction between the DFV and FV. In humans, the venous valve that is immediately distal to the DFV/FV junction is present in approximately 76-100\% of legs (Mühlberger et al., 2008; Moore et al., 2011). In this study the valves were present in
$95.8 \%$ of all specimens at a distance of $0-2.71 \mathrm{~mm}$ from the junction. The forms of the venous valve mainly include bivalve in the specimens as the same as that in humans. However, the number of venous valves in Macaca fascicularis is less than that in humans. This difference in the number of venous valves may require special attention when Macaca fascicularis is used to study CVI as animal models.

Animal models of CVI have been established using dogs (Lalka et al., 1988), swine (Jones et al., 2009), rabbits (Sawchuk et al., 1987), and rats (Pascarella et al., 2005). In these animal models, the venous pressure gradually decreases due to the open collateral circulation of the venous branches. We found that the outer diameters of the distal, middle, and proximal sections of the FVs are almost uniform, there are few venous branches in Macaca fascicularis, and no branches of the great saphenous vein are founded among the specimens included in this study. These features are valuable for establishing an animal model of CVI in Macaca fascicularis. In addition, there are no obvious histological differences in the venous valves between humans and Macaca fascicularis.

ZHANG, Y.; ZHANG, X.; XIONG, S.; NIE, B.; SHEN, M.; LIU, Z.; YUAN, J.; DANG, R. \& ZHANG, C. Anatomía aplicada de las venas femorales en Macaca fascicularis. Int. J. Morphol., 30(4):1327-1331, 2012.

RESUMEN: El objetivo fue comprender las características anatómicas de la válvula venosa en Macaca fascicularis y compararla con la de los humanos. Fueron disecados bilateralmente los miembros pélvicos (24 miembros de 12 animales) de cadáveres de Macaca fascicularis; las venas femorales (VF) fueron divididas en secciones distal, media y proximal. Se midió el diámetro externo de las VFs en cada sección. Las válvulas venosas se observaron microscópicamente y se tiñeron con H-E y tricrómico. Los datos para describir la válvula venosa humana se obtuvieron desde la literatura. No se encontraron venas safenas magnas entre los 24 miembros inferiores. Los diámetros externos de las VFs en las secciones distal, media y proximal fueron 3,53 $\pm 0,37 \mathrm{~mm}, 3,42 \mathrm{~mm} \pm 0,55$, y 3,37 $\pm 0,54 \mathrm{~mm}$, respectivamente. En la mayoría de los casos, hubo vena bivalva situada aproximadamente 0-2,71 mm debajo de la unión de la VF y la vena femoral profunda. El endotelio cubrió las superficies luminal y sinusal. Se observaron abundantes fibras de colágeno en las células endoteliales bajo la superficie luminal de las válvulas. Una red de fibras de elastina se encontró bajo la superficie del seno endotelial. Las células musculares lisas en las VFs se extiendían hasta el margen de la válvula. La válvula venosa del Macaca fascicularis es similar a la de los seres humanos, morfológica e histológicamente. Sin embargo, sólo hubo una vena bivalvular, y no se observaron venas safenas en Macaca fascicularis.

PALABRAS CLAVE: Vena femoral; Válvula venosa; Primate: Anatomía aplicada; Macaca fascicularis.

\section{REFERENCES}

Boffelli, D.; McAuliffe, J.; Ovcharenko, D.; Lewis, K. D.; Ovcharenko, I.; Pachter, L. \& Rubin, E. M. Phylogenetic shadowing of primate sequences to find functional regions of the human genome. Science, 299(5611):1391-4, 2003.

Bontrop, R. E. Non-human primates: essential partners in biomedical research. Immunol. Rev., 183:5-9, 2001.

Gillet, J. L.; Perrin, M. R. \& Allaert, F. A. Clinical presentation and venous severity scoring of patients with extended deep axial venous reflux. J. Vasc. Surg., 44(3):588-94, 2006.

Harker, L. A.; Kelly, A. B. \& Hanson, S. R. Experimental arterial thrombosis in nonhuman primates. Circulation, 83(6 Suppl.):IV41-55, 1991.

Inaba, M.; Adachi, Y.; Hisha, H.; Hosaka, N.; Maki, M.; Ueda, Y.; Koike, Y.; Miyake, T.; Fukui, J.; Cui, Y., et al. Extensive studies on perfusion method plus intra-bone marrow-bone marrow 
ZHANG, Y.; ZHANG, X.; XIONG, S.; NIE, B.; SHEN, M.; LIU, Z.; YUAN, J.; DANG, R. \& ZHANG, C. Applied anatomy of the femoral veins in Macaca fascicularis. Int. J. Morphol., 30(4):1327-1331, 2012

transplantation using cynomolgus monkeys. Stem Cells, 25(8): 2098-103, 2007.

Jones, G. T.; Grant, M. W.; Thomson, I. A.; Hill, B. G. \& van Rij, A. M. Characterization of a porcine model of chronic superficial varicose veins. J. Vasc. Surg., 49(6):1554-61, 2009.

Lalka, S. G.; Malone, J. M.; Cosentino, C.; Reinert, R. L. \& Bernhard, V. M. Canine model for surgical correction of chronic venous hypertension. J. Surg. Res., 44(4):359-70, 1988.

Moore, H. M.; Gohel, M. \& Davies, A. H. Number and location of venous valves within the popliteal and femoral veins: a review of the literature. J. Anat., 219(4):439-43, 2011.

Mühlberger, D.; Morandini, L. \& Brenner, E. An anatomical study of femoral vein valves near the saphenofemoral junction. $J$. Vasc. Surg., 48(4):994-9, 2008.

Pascarella, L.; Schmid-Schonbein, G. W. \& Bergan, J. An animal model of venous hypertension: the role of inflammation in venous valve failure. J. Vasc. Surg., 41(2):303-11, 2005.

Qi, S.; Xu, D.; Peng, J.; Vu, M. D.; Wu, J.; Bekersky, I.; Fitzsimmons, W. E.; Peets, J.; Sehgal, S.; Daloze, P. \& Chen, H. Effect of tacrolimus (FK506) and sirolimus (rapamycin) mono- and combination therapy in prolongation of renal allograft survival in the monkey. Transplantation, 69(7):127583,2000

Sawchuk, A. P.; Dalsing, M. C.; Emerick, S. C.; Waller, B. F.; Reilly, M. K.; Broadie, T. A. et al. A temporary distal arteriovenous fistula improves venous hemodynamics in a model of venous occlusion. Surgery, 102(2):256-62, 1987.

Thiranagama, R.; Chamberlain, A. T. \& Wood, B. A. Valves in Superficial Limb Veins of Humans and Nonhuman Primates. Clin. Anat., 2:135-45, 1989.

Traber, J.; Mazzolai, L. \& Lauchli, S. Epidemiology of chronic venous insufficiency--Swiss survey with surprising results. Praxis (Bern. 1994), 98(14):749-55, 2009.

\section{Correspondence to: Zhang Chuan-Sen and Dang Rui-Shan Department of Anatomy Second Military Medical University \#800 Xiangyin Road Shanghai 200433 CHINA}

Telephone: 0086-21-81870949

Fax: 0086-21- 81870955

Email: chuansen@yahoo.com

Received: 14-04-2012

Accepted: 22-05-2012 